ЧЛАНЦИ

UDC 255.2:340.114

CERIF: H130, H190, H210, H300

DOI: 10.51204/HLH_21101A

\title{
Isidora FÜRST*
}

\section{ТЕМИС И ДИКЕ \\ - ПРАВДА У ГРЧКОМ МИТУ И ТРАДИЦИЈИ}

Темияа је у античчким изворима ӣреgстиавлена као боїиға и ирророчиия, Тийанка, ћерка Гее и Урана. Она је симбол божанскоі реgа, ӣравичносиии, ирриродних закона и gобрих обичаја. Дике, Темияина ћерка, боїиюа је ӣравgе и ис-

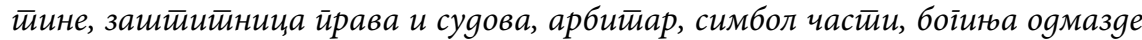
и казне. У раяу се анализирају хеленски йојмови йравgе, ирравичностии и закона оличени у феноменима иеемис и gике. Номос (закон) је исираван само ако је у хармонији с йемис - закон је вальан само ако је иравеgан. У раgу ће бити

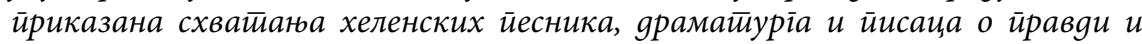

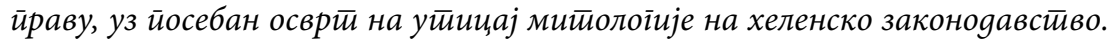

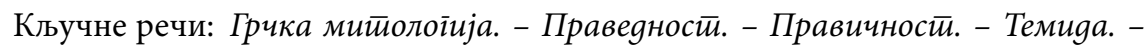
Дике.

\section{1. УВОД}

Тежња да било која одлука буде праведна и правична ${ }^{1}$ исказује се још у грчким митовима као усменим и писменим предањима Хелена

* Аутор је студент друге године основних студија Правног факултета Универзитета у Београду, isidora.first@gmail.com. Рад је измењена верзија рада изложеног на међународној студентској конференцији Iustoria 2021

1 „У старогрчком језику, у којем је настала разлика између правде и правичности, правда се означава речју dikaiosune, а правичност речју ерieikeia, док се на латинском језику правда каже iustitia, а правичност аequitas. Иако у садржинском смислу између правде и правичности нема суштинске разлике, правичност је ублажавање, па и исправљање строгости закона зарад индивидуалисане правде у неком изузетном случају који се, због своје несводиве особености, не може

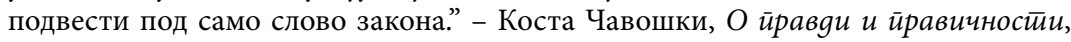
САНУ, Београд 2017, 255. 
о постанку и опстанку света, људским и божанским законима и општим вредностима. Разумевање права у античкој Грчкој проистицало је из тумачења људске природе и природних законитости, чији се основ проналазио у религији. Велики старогрчки песници, политичари и филозофи су дефинисали човека као религиозно биће и своја учења су изворно заснивали на митологији и религији. Митолошка спознаја природе, као део колективне свести, формирала је разумевање моралности, праведности и правичности, које се изражава у обичајима и законима кроз успостављање моралних и правних критеријума. Пратећи еволуцију идеје правде кроз дела старогрчких стваралаца, може се уочити примена новоприхваћених вредности у свакодневним обичајним и позитивним нормама. Правда, као примарно начело живота и права, у античкој Грчкој је у својим почецима била отелотворена у природном праву божанског порекла.

Полазило се од претпоставке да је правда достижна само онима који познају и говоре истину те је, у том смислу, од самог настанка почивала на нераздвојивом дуалном основу који је подразумевао сједињење права и морала. Неправда се дефинисала као оно што је супротно од правде. ${ }^{2}$ Појам правде је обухватао и неопходне карактерне особине појединаца или друштва, првенствено врлине части, поштења и здравог разума. ${ }^{3}$ Хеленски митови и закони античких богова, стога, немају само теоретски значај већ и практичну вредност која се огледа у уградњи идеје правде и реда у правно и политичко стваралаштво.

У раној грчкој култури и поезији, правда се означавала специфично вишезначним старогрчким терминима themis и dike, који су у најширем смислу персонификовали космички ред, природно право и законитост. Изрази темис и дике су се истовремено користили у општем означењу правде (било људске било божанске), етичких вредности, праведности, реда, закона, судског поступка и добрих обичаја. Представљали су, с једне стране, богиње (Темиду и њену ћерку Дике) које поседују божанску мудрост и знање о праву и, с друге стране, метафоре пожељних правних и етичких вредности.

Темида је у античким изворима описана као богиња и пророчица, оличење божанског реда, природних закона, заштитница права и судова. Прва богиња правде је била Зевсова љубав, главна саветни-

2 Неправда као супротност правди по први пут се појављује у Хераклитовој филозофији. Видети: Heraklit, Fragmenti (priredio Miloš Đurić), Grafos, Beograd 1979. frg. 42.

3 Miloš N. Đurić, Istorija helenske književnosti, Zavod za udžbenike i nastavna sredstva, Beograd 1996, 85-88. 
ца и симбол воље богова. Насупрот њој, стајао је nomos као симбол обичаја, реда и позитивних закона. ${ }^{4}$ Номос је створен од људи али је исправан само ако је у хармонији са темис те је закон ваљан само ако је праведан. ${ }^{5}$ Дике, Темидина наследница, богиња је правде и истине, представница праведности и законитости, заштитница судског поступка, арбитар, симбол части, богиња одмазде и казне. Идентитет Дике је био нијансиран у тој мери да је у најширем смислу значио равнотежу, универзални космички поредак и меру свих ствари. Најстарије представљање правде у античкој књижевности се појављује у Хомеровим еповима „Илијади” и „Одисеји”, који се, филозофски посматрано, могу сматрати текстовима о правди и неправди. ${ }^{6}$ Дике, као богиња правде и казне први пут се помиње код Хесиода, када се идеја права и правде везује за разумевање богова, тумачење њихових радњи и отворених или скривених порука. Хесиодови богови постају носиоци обичајних начела и вредности, па частност, поштовање дате речи и полагање заклетве јесу важна обележја Хесиодове дике. ${ }^{7}$

Терминологија о праву, правди и правичности коришћена у старогрчким изворима комплексна је и садржајна у тој мери да је веома тешко истаћи сва научна схватања и тумачења која се баве њоме. ${ }^{8}$ Поезија и пресократовска филозофија садрже богатство метафора, концепција и категорија, мерила вредности и врлина, истине и исправности, као и идеје о праведном односно божанском поретку космоса у целини и његовој равнотежи. ${ }^{9}$ Темис, номос и дике су уједно филозофскоправни појмови и означења митских божанстава, а употребљавани су на различитим међусобним релацијама. Хеленски филозофи, од времена пре Сократа до хеленистичког доба, дали су нове дефиниције темис и дике као апстрактних појмова. Филозофске школе пре Сократа отпочеле су развој хеленске научне етике, ${ }^{10}$ Сократ је правду видео у доброти као врховној врлини, ${ }^{11}$ Платон је

4 Jasminka Hasanbegović, „Predgovor”, Jasminka Hasanbegović (ur.), Pravo i pravda 2013, Univerzitet u Beogradu - Pravni fakultet, Beograd 2019, 8.

5 Ibid.

6 Željko Kaluđerović, Presokratsko razumevanje pravde, Izdavačka knjižarnica Zorana Stojanovića, Sremski Karlovci - Novi Sad 2013, 23.

7 Ibid., 70.

8 Sima Avramović, „Gnome dikaiotate - pravo, pravda i pravičnost u atinskoj sudnici”, Jasminka Hasanbegović (ur.), Pravo i pravda 2013, Univerzitet u Beogradu - Pravni fakultet, Beograd 2019, 19.

9 Karl - J. Hölkskamp, „Written Law in Archaic Greece”, Proceedings of the Cambridge Philological Society 38/1992, 99.

10 Miloš Đurić, Istorija helenske etike, BIGZ, Beograd 1976, 99-100.

11 Ibid., 254-256. 
праведност посматрао у односу на заједницу и државу, ${ }^{12}$ а Аристотелово стваралаштво дало је прво разумевање правичности ${ }^{13}$ и објединило је мисли претходника. Сусрет доктрина античких филозофа налази се у преиспитивању старих схватања о општим божанским законима, врховним нормама и човековој моралности. Старогрчки филозофи поставили су темеље савремених учења о правним феноменима, али како је тема о развоју хеленске етике била преобимна да би се разматрала у оквиру овог рада, у наставку следи анализа трансформације религијске идеје правде кроз сачуване митове и друге литерарне изворе.

Темис је у време родовског уређења представљала највише правно мерило, да би њен утицај био смањен у почецима развоја полиса̄ који су постепено мењали примитивна обичајна права постала из древних религијских схватања. ${ }^{14}$ Реч номос је у раном периоду грчке историје означавала право и закон (обичај, ред, пропис и начело), а од $\mathrm{V}$ века п.н.е та се реч односила и на писани закон. ${ }^{15}$ Термин дике писан малим почетним словом (за разлику од властите именице Дике, која означава богињу правде, ћерку Зевса и Темиде), односи се на индивидуално означење правде, али и на приватну тужбу којом се покреће судски поступак те стога и на суђење, парницу и пресуду. Исти израз се може односити на различите врсте правде: божанску и људску, религијску и световну, и обичајну и законску. ${ }^{16}$

Код старих Римљана персонификација правде налазила се у једној богињи, Јустицији, а стари Грци су правду и све њене облике препознавали у лику двеју богиња - Темиди и Дике. ${ }^{17}$ Постоје и друге значајне разлике између римских и грчких богиња и појмова права и правде. Римски ius има власт над људима и стварима, док дике само потражује услуге уз позив на лични осећај дужности. Онај ко има јус једноставно узима оно што му припада, док дике даје ономе који то заслужује. Јус зависи од силе, а дике, иако подједнако снажна, силу не укључује. Одлуке магистрата у Грчкој никада нису биле називане 'дике' јер нису имале снагу и ауторитет одлука судија; насупрот томе, одлуке магистрата у Риму могле су бити

12 К. Чавошки, 8.

13 Ibid., 23-24, Правичност наступа онда када општост прописа онемогућава достизање правде.

14 Jane Ellen Harrison, Themis - A Study of the Social Origins of Greek Religion, Cambridge University Press 1912, 484.

15 S. Avramović, 19-20.

16 Ibid., 21-22.

17 J. Hasanbegović, 8. 
'јура', пошто је њихов извор била највиша сила - моћ људи. Иако јустиција у почетку није била персонификација божанства (већ се тако схватала тек од доба Цезара), римска правда се поред грчких значења односила и на међународне односе и рат. ${ }^{18}$ Римска богиња Јустиција била је персонификација праведног рата и у њој се налазило оправдање за велике походе и освајања. У време Августове владавине, правда је, заједно с хармонијом, миром и пољопривредним благостањем, била врховна врлина. Као и дике у старој Грчкој, јустиција је сматрана нужним делом грађанског права и важном особином доброг државника. ${ }^{19}$

Иако постоје многобројни извори сазнања о богињама правде који потичу из раног периода хеленске историје, највише записа о митолошком предању које се односи на Темиду оставио нам је римски песник Публије Овидије Насон. Његово стваралаштво одликује повезивање и обједињавање грчких и римских божанстава, а дело „Метаморфозе” посебно говори о Темидиној улози у постанку света и спасењу људског рода. У „Метаморфозама” је опеван је мит о преображају Хаоса који се раздвојио на четири елемента (земљу, море, ваздух и небо) и завршио постанком становника земље од воде и ваздуха. ${ }^{20}$ у четири људска века, потомци Гиганата (Титана) почели су да презиру богове и подигли су се против Олимпа. ${ }^{21}$ Врховни бог Јупитер је казнио људски род великим потопом, ${ }^{22}$ који су преживели једино праведни Деукалион (Прометејев син) и побожна Пира. Деукалион и Пира су лађом стигли до брда Парнас изнад Делфа и обратили се Темиди с молбом да помогне пропалом свету и надокнади губитак људског рода. Темида, богиња закона и правде, ћерка Урана и Гее, била је главна пророчица Делфа пре Аполона. Спроводећи божји план о стварању новог света и народа, наложила је Деукалиону и Пири да оду и поврате свет рекавши им: „Велике матере кости за леђа бацајте себи." Деукалион и Пира су се ослонили на пророчанство богиње Темиде: „Или ме памет вара, или је пак (јер пророчанства су света и никад не наводе на грех!) наша прамајка земља, а камење су кости о којима богиња говори. Њих нам је заповеђено да бацамо преко себе." Темидино пророчанство се остварило те су

18 Stefan Weinstock, Divus Julius, Oxford University Press, London 1971, 243, 246-247.

19 John Bertrand Lott, „An Augustan Sculpture of August Justice”, Zeitschrift für Papyrologie und Epigraphik 113(1996), 267-268.

20 Publije Ovidije Nason, Metamorfoze (preveo Tomo Maretić), Matica Hrvatska, Zagreb 1907, heks. 1-20.

21 Ibid., heks. 150-160.

22 Ibid., heks. 275-295. 
од земље и камења које је преко рамена бацао Деукалион настали мушкарци а од камења које је бацала Пира настале су жене. ${ }^{23}$

Овидије, као и многи антички песници, пружа двојаки приказ Темидине појаве. Темида је истовремено приказана као божанство, односно богиња правде и као персонализација апстрактног појма 'темис' односно идеја правде. Основна идеја Овидијевог епа јесте да целокупна људска историја представља метаморфозу, односно последичну промену обличја, а да понашања људи повлаче казну или помиловање по божјој вољи и милости по принципу праведности. Нетакнути злом и греховима људског рода, Деукалион и Пира су због своје доброте и поштења поштеђени од страдања у потопу и изабрани су да, уз божју идеју и помоћ, учествују у стварању новог света и нових људи који треба да прихвате и спроводе начела праведности и побожности.

У античкој Грчкој постојало је неколико варијанти митова о потопу и праведницима Деукалиону и Пири. Наиме, поред мита који је опевао Овидије вековима након првог помена Темиде, позната је и легенда о Зевсовом кажњавању људског рода због приношења људских жртава. Према трећем предању, са̂ма богиња Темида одговорна је за потоп, након чега је обновила свет не добивши претходно сагласност од Зевса. ${ }^{24}$ Мит о великом потопу којим је кажњена људска злоба представљен је и у Епу о Гилгамешу и библијској легенди о Ноју. Заједничко различитим верзијама легенди о великом потопу јесте изражавање моралног става о постојању божанске правде која бескомпромисно кажњава најгоре људске особине и ритуале противне религијским принципима.

Темида и Дике су биле саставни и неизбежни део грчког политеизма логички сложеног у олимпски систем. Представнице правде биле су неопходне за објашњење морала који је био поистовећен са религијом. Пошто су Хелени временом боговима приписали сва друштвена, психолошка и морална својства која поседују људи, поред оних материјалних, долазило је до несугласица и неслагања међу великим мислиоцима тога доба око исправног схватања божанске правде. Књижевници су давали романсиране приказе или користили божанства због њихове симболике а први филозофи су хитро наступали са презрењем према народним предањима. ${ }^{25}$ Велики број начела постављених током развоја старогрчке хуманистике има своје место и у савременом друштву, а међу њима истичу се као најважнија - праведност и правичност.

23 Ibid., 315-415.

24 Robert Grevs, Grčki mitovi, Miba books, Beograd 2017, 142-146.

25 H. D. F. Kito, Grci, Prosveta, Beograd 2008, 236-237. 


\section{2. ТЕМИС И ДИКЕ - СЕМАНТИЧКИ ПРИСТУП}

У научним и академским круговима још увек није постигнута сагласност у вези с тачним значењима и ваљаним употребама речи темис и дике као моралним и правним концепцијама. ${ }^{26}$

Размишљања старих Хелена о праву и законима су била усредсређена на основна питања суштине закона и основе њихове обавезности. Током развоја хеленистичке мисли, одговори на ова питања тражени су у тумачењу три феномена: темис, дике и номос. Реч темис је изражавала најранија разумевања правног правила које се своди на вољу богова, а реч дике је означавала нужну правичност исказану у међуљудским односима. Грчка митологија је богињу Дике окарактерисала као чувара оног права које је Зевс давао људима те је имала само законодавну, акузаторну и казнену функцију. Током VIII века п.н.е. појму темис је давано значење божанске воље, док је дике повезивана са решавањем текућих спорова. Иако се веровало да ниједан од закона није потекао од законодавца смртника, дике је имала мање религијску конотацију од темис. ${ }^{27}$

Карактеристична одлика грчког номолошког схватања јесте да централну улогу у одговарајућој друштвеној организацији, осим природе правног поступка, злочина, казне, правичне или неправичне пресуде, чини добро или лоше, исправно или погрешно понашање. Стога, темис и дике, било као богиње, било као идеје, јесу конститутивни елемент мирног поретка свих ствари, како људских тако и божанских. Оба божанства (заједно с номосом) представљају сложену концепцију која има променљиву улогу у интелектуалном и духовном животу античке Грчке. ${ }^{28}$

Темис је сила која одржава колектив, она отелотворује инстинкт заједнице и највиши социјални императив. Од оличења онога што је по природи правилно, апстракција темис временом постаје саставни део законодавства као права и божанског морала. Богиња Темида никада није била искључиво предмет религијског култа већ и извор различитих религијских представа и приказа, ${ }^{29}$ због чега се појам темис на свом еволутивном путу појављује у многобројним формама. ${ }^{30}$

26 S. Avramović, 19-20.

27 Marek Maciejewski, „The Relationship between Natural and Statutory Law in Ancient and Medieval Concepts", Księgarnia Akademicka, Politeja 48/2017, 8.

28 K.-J. Hölkskamp, 99.

29 J. E. Harrison, 485-486.

30 Ibid., где Харисон каже да се Темида појављује као врховна пророчица и гласник богова, потом бива поистовећена са скупштином у Хомеровим еповима, да би 
Сва својства која су пратила темис у првим временима хеленске историје полако постају део дике; исто тако, све особине Темиде постају особине њене ћерке Дике. Дике је тако преузела овлашћења врховног судије. Међутим, премда је убрзо сматрана главним симболом правде, никада није имала религијски смисао истоветан ониме који је носила Темида. Апстракција темис задржала је изворно метафизичко значење природног божанског права, а апстракција дике обухватила је стара тумачења на начин који је погодовао законодавном процесу.

Митолошка прича о Темиди и Дике обједињује древну и доследну разлику између божанске и људске правде - између архетипске, ванвременске идеје (коју представља Темида) и њене манифестације у људском времену и схватању (коју представља Дике). Дике је подложна промени, може се прилагођавати или чак и нестати, а Темида је увек стабилна и присутна, као део људског психолошког састава. У савременом грчком језику, термини који у свом корену имају реч дике се односе на административни систем спровођења правде, док је реч темис његова персонификација. Дике се мења уз промену културних норми и промену перцепције праведног и исправног, а темис значи вековну постојаност и подсећа законодавце и бирократе на извор њихових закона. ${ }^{31}$

Поједини аутори сматрају да термин дике у ужем смислу није обухватао етичку исправност у архаичном периоду, већ се односио на правне појмове везане за судски поступак и закон, а тек касније се проширио на дефинисање универзалне космичке силе. У том смислу, Дике је преузела материју морала од Темиде, и то без древних религијских компонентни. Дике, као регулатор правног и политичког понашања, била је неопходни услов економског просперитета јер регулише споразуме и поравнања у имовинским споровима. Антички песници пак, дике употребљавају за описивање законитог и мирног решавања међуљудских сукоба, насупрот насилним и незаконитим радњама. Дике се истовремено појављује као именица и као придев, користећи се у два основна значења самог појма: једном који описује исправно понашање и другом који описује понашање у складу са законом. Карактеристичне радње које су у сагласности с дике, у правнополитичком контексту, јесу оне радње које су мирољубиве, ненасилне и неповређујуће. Стога, дике представља својеврсног медијатора, судију, пресуђење, као и санкцију за повреду законитости. ${ }^{32}$

након развоја полиса и законодавства била опште схватање правде и морала схваћено као основ за правни поредак.

31 Pamela Donleavy, Ann Shearer, From Ancient Myth to Modern Healing (Themis: Goddess of Heart-Soul, Justice and Reconciliation), Routledge, London - New York 2008, 88.

32 Michael Gagarin, „Dike in Archaic Greek Thought”, Classical Philology 69(3)/1974, $186-189$. 
Реч дике јавља се у најразличитијим контекстима било у стиху било у прози, те тако некада означава чак љубав, пиће и размишљања о космологији. Независно од тога, ове речи се у архаичном периоду превасходно употребљавају у области оног што се данас назива имовинско право и законито понашање, заједно с њиховим политичким импликацијама. Како се људи организују у веће друштвене целине (полисе), материјално благостање све више зависи од постојања друштвено прихваћених, успостављених, ненасилних, мирних начина за стицање и размену имовине и решавање имовинских спорова. Тај процес је започео током архаичног периода због чега су настала многа правила економског понашања у складу са дике. Опште схватање је било да је одговарајући правни поступак (дике) изузетно важан за општу добробит полиса, а да његово кршење дугорочно шкоди не само појединцима у питању, него и целој заједници. Пошто су Дике и Зевс доведени у корелацију, повреда Дике сматрала се преступом против богова. Међутим, упркос томе што је кажњавање преступника било неопходно како би се отклонила увреда нанета боговима, Дике још увек не подразумева моралну вредност по себи већ само понашања која су - споља посматрано - усклађена са законима. Дике није имала општи морални значај све до Платонове и Аристотелове филозофије. ${ }^{33}$

Основни аргумент у прилог томе да појам дике у раном грчком друштву није нужно имао морални садржај, проистиче из значаја који се придаје унутрашњим побудама које покрећу хеленског човека на предузимање радњи. Пошто се сматрало да неки људи делају на одређени начин искључиво зато да добију одобрење или избегну неодобравање осталих чланова заједнице, а не из личног убеђења о (не)исправности таквог понашања у складу с дике, онда ни дике не мора подразумевати моралност таквог понашања. У друштву у којем се мотиви неких чланова заједнице своде једино на обазривост, те они делају само из страха од срамоћења или прогона, уместо из интимног уверења, дике не мора подразумевати врлину, то јест моралну побуду. ${ }^{34}$

\section{3. ПРАВДА У ХЕЛЕНСКИМ ЕПОВИМА}

Прво време историје хеленске етичке мисли обележено је мистичким моралом. Најпознатије мистеријске религије су биле елеусинска (култ Деметре и Персефоне), самотрачка (култ Кабира и

33 Ibid., 196-197.

34 Matthew W. Dichie, „Dike as a Moral Term in Homer and Hesiod”, Classical Philology 73(2)/1979, 92. 
Кадмила) и орфичка (култ Диониса). ${ }^{35}$ Древне хеленске религије су биле посвећене прихватању и ширењу знања, духа, искуства и мудрости предака. У све развијенијим знањима хеленског човека појединац полако долази у центар разумевања света и космичких сила, што је утицало на стварање митова као приказа човековог „ја” уједињеног с космосом и природом. Над таквом јединственом целином стоје хеленски богови као отелотворења идеја и феномена, а уз то и као мерила животних вредности за старе Грке. ${ }^{36}$

Преовладавањем мистичко-теолошког схватања света, настају величанствени Хомерови епови који хуманизују целокупан митски свет и правду и правичност представљају по први пут из угла појединца и друштва. У „Илијади” и „Одисеји”, еповима који опевају и величају херојски дух, праведност и правичност као идеје о темис и дике, показују се у мотивима, намерама и понашању учесника догађаја, већином хероја. Основ херојског морала била је част, односно морална слава, стечена ратним успесима, херојским делима и видљива у правима која им по тим заслугама припадају.

Хомеров еп „Илијада” пева о историјски непотврђеном Тројанском рату, који се крајем микенског периода водио између Ахајског племена и Тројанаца (највероватније Дардена), на Средоземном северозападу Мале Азије, јужно од почетка мореуза Дарданела или Хелеспонта. Град Троја или Илеј повезивао је Грчку и Малу Азију, односно Егејско и Црно море. Такав географски положај омогућавао је Тројанцима ефикасну трговину и наплату намета бродовима који су пролазили кроз мореуз; економски напредак Троје Грцима је био довољан разлог за рат и освајање Троје, односно целог Хелеспонта и других богатих територија око Црног мора. Постојање Троје углавном се прихвата као историјска чињеница, имајући у виду историјске прилике и археолошке изворе. ${ }^{37}$ Било како било, песник је - у духу народних митова - повод за Тројански рат видео у Парисовој (који је био син тројанског краља Пријама) отмици Хелене, жене спартанског краља Менелаја. ${ }^{38}$ Свака од четири целине Хомеровог епа о Илијади изражава ондашња схватања морала, врлина и божанских закона.

35 M. Đurić, Istorija helenske etike, 3.

36 Ibid., 18.

37 Vil Djurant, Istorija civilizacije: Život Grčke, Narodna knjiga, Beograd 1996, 46-48.

38 Док Хомеров еп инсистира на романсираном поводу за Тројански рат, „Кипарски еп” песника Стасина из VII века п.н.е. пева о покољу пред Тројом као одлуци богова да реше проблем пренасељености. „... Зевс виде то, сажали се (на земљу) и у своме мудром уму измисли како да свехранитељку земљу олакша од људи..." - Miroslav Marković, Studije o religiji antike, Jasen, Nikšić 2001, 28-31. Стасинов еп придаје веома велики значај учешћу богова у Тројанском 
Почетак епа говори о највећем грчком ратнику Ахилу, сину морске богиње Тетиде и тесалског краља Пелеја. Гневан што му је Менелајев брат Агамемнон отео вољену робињу Брисеиду, Ахил је одбио да се бори уз Грке против Троје. Био је повређен неправдом која му је учињена, па се и његова мајка Тетида обратила Зевсу за помоћ. ${ }^{39}$ Неизвесне борбе Ахајаца и Тројанаца низале су се због сукоба богова који су били наклоњени различитим странама. ${ }^{40}$ Иако су добили рат и поразили Тројанце, главни актери и јунаци Илијаде били су после коначног исхода рата лично поражени. ${ }^{4}$

У основи „Илијаде” представљена је нова, а можда чак прва хеленска идеја правде и правичности, изражена самим понашањем учесника које су надгледали и усмеравали богови. Композиција епа садржи развијање радњи које се доживљавају као праведне или неправедне, док казне за грешнике утичу на укупан ток догађаја. Непосредан повод за рат била је отмица лепе Хелене, као чин нечастан на моралном и личном плану. Госту Парису пружено је највише гостопримство, а он је прекршио моралне норме и повредио добре обичаје отевши домаћину вољену жену која му је по закону „припадала”. Увреда, као неправедна повреда части, могла је да се реши двобојем између Менелаја и Париса. Али, како двобој није одржан, Менелај и Агамемнон су повели ахајску војску у Троју да би казнили кривца Париса. У даљем току догађаја Агамемнон је учинио велику неправду хероју Ахилу узевши за себе Ахилову робињу Брисеиду. Акт увреде је толико разљутио Ахила да је одбио да даље учествује у борбама и вратио се у битку тек након што је Агамемнон признао своју грешку, обећао одговарајућу накнаду, вратио му Брисеиду и јавно изјавио да је није злоупотребио. Богови су, такође, обећали Ахилу високу накнаду за повратак у рат. На основу обичајног права (темис) уз асистенцију агоре, успостављена је за Ахила правда (дике) као равнотежа између његових заслуга и његових права. ${ }^{42}$

Ахилове заслуге проистичу из његових ратних успеха, ратничке вештине и херојске храбрости због којих му припада највећа част. Поштовање части било је основа хеленског етичког поретка те је увреда сматрана највећом могућом трагедијом за хероја. ${ }^{43}$

рату, међутим; неспорно је, међутим, да је и Хомер био под значајним утицајем митологије.

39 Homer, Ilijada (preveo Miloš N. Đurić), Dereta, Beograd 2015, pev. I.

40 Ibid., pev. II-XIV.

41 V. Djurant, 71.

42 Ž. Kaluđerović, 23-34.

43 Ахил је од богова тражио помоћ и поштовање, што је и рекао својој мајци Тетиди. Видети: Homer, Ilijada (prev. М. N. Đurić), pev. I, 340: „Мајко, кад си 
Ахилова борба за очување херојске части као врховне врлине била је у сржи његове одлуке да се врати у Троју. Бирао је између дугог, али неславног и кратког, али славног живота, па је у складу с херојским моралом одлучио да радије славно погине пре него да изгуби славу и част. ${ }^{44}$ Иако је Ахил неспорно најупечатљивији лик у „Илијади”, лик Хектора, тројанског јунака и сина краља Пријама, надвисује га у смислу моралне величине. Хектор не ратује за славу или освету, не бира између славе и живота, већ ратује јер мора да одбрани своју породицу, дом и отаџбину. ${ }^{45}$

У епу „Одисеја” поимање правде огледа се у праведном поступању и правичним одлукама унутар породице, полиса, и између полиса. Хомер опева Одисејеве авантуре у двадесет година одсуствовања са родне Итаке. Након десет година ратовања пред Тројом, Одисеј се заједно са својом посадом борио с Киклопима, успротивио богињи Кирке, пловио поред острва сирена, доживео бродолом у мореузу код Сциле и Харибде и на крају провео седам година на острву нимфе Калипсо. ${ }^{46}$ Ипак, упркос бројним догађајима, искушењима, па и Калипсиној љубави, био је одлучан да се врати своме дому на Итаки, жени Пенелопи и сину Телемаху.

У Одисејевом двадесетогодишњем одсуству с Итаке појавио се интерес многих за успостављање нове власти коју би омогућила Пенелопина удаја. Бројни Пенелопини просци окупирали су двор на Итаки и бесрамно трошили Одисејево богатство. Схватања правде и правичности огледају се у сукобу између Пенелопиних просаца и Одисеја. Права просаца, с једне стране, и права Одисеја и његовог сина Телемаха на њихово убиство ради очувања породице и краљевства, с друге стране, могу се у етичком смислу посматрати у две фазе развоја догађаја. У првој фази, позиција просаца била је морално

већ маловечним родила мене, / да ми је барем Диве Олимпљанин громовник вишњи / одао част! Ал' сад ми није заклонио образ, / силни краљ Агамемнон Атрејић погрди мене, / сам ми уграби дар и узе и сада га има."

44 Ахилова дилема између очувања херојске части и живота приказана је у његовом обраћању мајци Тетиди пре наставка Тројанског рата. Ibid., pev. IX, 410: „.... ако останем овде и ратујем около Троје, / нема ми повратка кући, ал' слава ми пропасти неће; / ако ли се кући вратим у вољену очинску земљу, / нема ни славе ни дике, ал' дуг ћу имати живот, / те ме неће смрт и скончање брзо затећи."

45 M. N. Đurić, Istorija helenske književnosti, 74-82.

Homer, Ilijada (prev. M. N. Đurić), pev. VI, 440: „... ал’ ме је Тројаца стид и дугоскутих Тројанки њиних, / ако бежао будем из борбе ко плашљивац какав. / То ми забрањује срце, јер навикох увек да честит / будем и храбро се борим мед првим Тројанцима свагда, / велику текући славу и оцу и самоме себи.”

46 Homer, Odiseja (preveo Panajot Papakosopulos), Karpos, Loznica 2013, pev. IX-XII. 
прихватљива: Одисеј је био сматран мртвим јер о њему није било вести двадесет година, а Пенелопа се није у међувремену поново удала, док је полису био потребан владар (Телемах је још увек био превише млад да би наследио престо). Просидбе су стога биле легитиман чин дозвољен према обичајном праву (темис). Међутим, у другој фази просци су повредили добре обичаје и прекорачили своја обичајна овлашћења тиме што су запосели Одисејев двор, понашајући се дрско и обесно. На Скупштини полиса, просци су показали намеру да на сваки начин преузму власт, одлучивши да убију Одисеја уколико се икада врати на Итаку. Непоштовање обичаја дало је за право Одисеју да примени казне према принципима дике и да убије просце зарад успостављања реда у полису. ${ }^{47}$ Овај догађај осликава хеленски принцип успостављања правде и специфичну сразмеру казне спрам повреде права и друштвеног морала.

За разлику од ратничких, агресивних и импулсивних одбрана части и угледа хероја из „Илијаде”, у „Одисеји” је уочљив преображај индивидуалних идеала војничке аристократије ка рационалном планирању и стрпљивом спровођењу циљева у општем интересу полиса. Ахил и Одисеј су две стране истог лика јег заједно осликавају основне особине хеленских јунака: храброст и рационалност, снагу и мудрост, неустрашивост и предузимљивост. Ахил је у „Илијади” био у сировој, суровој и фанатично упорној одбрани своје херојске части, без обзира на шире последице. Одисеј је био мудар, стрпљив човек чврсте духовне снаге и виспрени планер који је упорно ишао ка своме циљу, доследан, сигуран у своје највеће вредности, свој дом, своју породицу и своју владарску позицију те стога никада није поклекнуо пред разноврсним изазовима који би га одвојили од тих вредности.

Временом, херојски дух и грчке колонијалне тежње у књижевности уступају место приказивању реалног живота појединца и друштва. Исто као што се мењао идеал човека, мењао се и поглед на хеленске богове. „Као последица тог преображавања и као резултат моралног утицаја на замисао божје улоге појављује се и преображавање боговског идеала: богови нису више претежно саможиви чувари и осветници својих права, ни ћудљиви посматрачи људских борби и болова, него озбиљни заштитници правних и моралних односа међу људима."48 Епови настали након „Илијаде” и „Одисеје” сведоче да је у античкој књижевности дошло до промене у приказивању моралних ставова, правде и правичности.

47 Ž. Kaluđerović, 47-53.

48 M. N. Đurić, Istorija helenske književnosti, 85-88. 
Песник Хесиод, чувен по епским песмама „Теогонија (Постанак богова)” и „Послови и дани”, удаљава се од херојских врлина људи и приказује богове као носиоце моралне моћи и чуваре правде. Песник заговара идеју да су и правда и правичност божанског порекла, да су богови творци и чувари праведности и да је религија заштитница правичности. „Хесиод постаје гласник нове религије која у божанству види моралну моћ у супротности према боговима Хомера и сваке примитивне религије." ${ }^{49}$ Према предању, одржано је песничко такмичење између Хомера и Хесиода у којем је победио Хесиод. Иако није вероватно да се то такмичење заиста догодило, пошто се претпоставља да је Хесиод живео око сто година после Хомера, предање говори о друштвеним променама које су се догодиле у античкој Грчкој у том периоду. Хомер је описивао вредносне системе војничке аристократије, а Хесиод је певао о тешком животу обичних људи, испуњеном мукотрпним радом и неправдом. Романтични прикази краљева и хероја уступају место друштвеном реализму, који је захтевао нове моралне поуке. ${ }^{50}$

У епу „Теогонија” Хесиод поставља питања стварања космоса (космогонија) и постанка богова (теогонија) и сачињава генеалогију богова, то јест представља родослов и историјат богова. Уз опис постанка богова, песник даје опис постанка Космоса из Хаоса, као почетка и промене свега постојећег. ${ }^{51}$ Из Хаоса су настали Геа (Земља) која је мајка свих бића, Тартар (Подземље), Ереб (Тама) и Ерос (Љубав). Геа је самостално родила Урана (Небо), а с њим је добила шест мушких и шест женских Титана, међу којима и Темиду, богињу праведности и законитог поретка. ${ }^{52}$ Улоге Титана биле су мање или веће у митологији и скоро да нису постојали религијски култови који су их пратили. ${ }^{53} \mathrm{Te}-$ мида је била Зевсова друга жена и мајка богиња четири годишња доба и судбине, односно богиња правде, законитог поступања и мира. Темида и њена ћерка Дике биле су заштитнице праведности и закона. ${ }^{54}$ Зевс је представљао космички морални поредак који је значио мерило за деловање људи и богова. ${ }^{55}$ Божји родослов дат у „Теогонији” пока-

49 Ibid., 129.

50 P. S. Kohan, 75, 76.

51 Ан-Мари Битен, Сйара Грчка, Clio, Београд 2010, 168-169.

52 Hesiod, Poslovi i dani, Postanak bogova, Homerove himne (preveo Branimir Glavičić), Demetra - Filološka biblioteka Dimitrija Savića, Zagreb 2005, Postanak bogova heks. 115-135.

53 Hesiod, Theogony, Works and Days, Testimonia (edited and translated by Glenn W. Most), Harvard University Press, Cambridge - London 2006, Introduction XXVIII-XXIX.

54 Hesiod, Poslovi i dani, Postanak bogova heks. 905-910.

55 M. N. Đurić, Istorija helenske književnosti, 129-131. 
зује да је у са̂мој основи грчке митологије стајала идеја, то јест вредност правде и закона, јер су најмоћнији богови били персонификација правичности и других врлина.

У свом епу „Послови и дани” Хесиод даје критику свога друштва, чије је тегобе и неправде и сам осетио. Основно морално начело, по Хесиоду, чине правда и рад. ${ }^{56}$ „Послови и дани” пружају савете о пољопривреди, поморском животу и правилима других врста економског, друштвеног и религијског понашања. ${ }^{57}$ Говорећи о правди, Хесиод се позива на Зевсову ћерку Дике, богињу правде која указује на неправедне пресуде које доносе главари гладни дарова. На овај начин песник изражава неповерење према законима и власти и износи песимистичан став о добу у коме је мало праведности. ${ }^{58}$

У Хесиодовим делима представљен је људски закон као независан од закона богова. Хесиодова дела нису имала само уметнички значај већ су и прва дала слику митолошких божанстава и њиховог односа према људима. Већ у наредном периоду хеленске историје долази до првих покушаја кодификације, од којих су најзначајније реформе великог атинског законодавца Солона. Митолошка правда приказана у Хомеровим и Хесиодовим делима доживљава препород у почецима законодавства.

\section{4. ДИКЕ И ПОЧЕЦИ ЗАКОНОДАВСТВА}

Прве велике правне новине у старој Грчкој и прве кодификације у Атини приписују се Дракону и Солону. Док су Драконови ригорозни закони представљали прве писане законе, Солонове законодавне

56 У првом делу епа, обраћајући се брату Персеу, Хесиод указује на обавезу да се не лаже под заклетвом јер то доводи до кривих пресуда, то јест до жртвовања правде. Hesiod, Poslovi i dani, Poslovi i dani, heks. 215: „Персе ти слушај правду а насиље немој проводит. / Јер је насиље зло за биједна смртника, а неће / лако се њиме носити ни одличник, већ ће под њиме / клонути кад га снађу јади. Но пут што пролази другуд / бољи је онај што води до правде. Јер Правда на крају / увијек надјачава силу. Кад настрада, зна то и луда, / јер се заклетва одмах уз криве пресуде нађе, / Правде чује се крик кад је вуку куд воде је људи / гладни дарова, а криво пресуђујућ кроје правицу."

57 Hesiod, Theogony, Works and Days, Introduction XXXVI-XXXVII.

58 Hesiod, Poslovi i dani, Poslovi i dani heks. 260: „Ту је и дјевица правде што родила се од Зеуса, / Дична и коју бози што на Олимпу живе часте, / Кад је кад повреди тко криво оклевеће кога, / одмах она седа крај оце Кроновог сина, / Тужи се њему на људску неправичност, како би народ / Гријехе испаштао својих главара што жалосне мисли / Снују другамо скрећућ правицу кад говоре криво. / Пазите на то главари, ви који сте гладни дарова, / судите право а криве заборавте пресуде посве." 
реформе су биле друштвене, аграрне, политичке и државне. Солон је изабран 594. године п.н.е. за представника народа и будућег атинског законодовца. Донео је велике промене у државну и друштвену организацију: укинуо је Драконове законе, извршио је поделу становништва према имовинском стању и приступио је реорганизацији државних органа. Поред тога, Солон је донео законе који су можда мање погодовали култури и обичајима Атињана, али су поправили положај најсиромашнијих, укинуто је дужничко ропство, a реформски су били и закон о забрани ружења мртвих и забрани грђења живих, закон о завештањима и путовању жена, о жаљењу за покојницима и о празновању празника. Солонове се реформе могу сматрати подједнако строгим и праведним. Те социјалне промене су убрзо прихваћене у атинском друштву, а Солон је, дубоко верујући у просперитет који ће наступити, изјавио да је довео у склад насиље и правичност. ${ }^{59}$

Солон је међу првима приметио могућност несагласности између темис, дике и номоса. Иако је сматрао да је несагласност међу тим суштински различитим врстама права донекле неизбежна, покушао је да ублажи последице њиховог потенцијалног конфликта тиме што се трудио да људски закон што више приближи отелотворењу божанског закона. ${ }^{60}$

Према Хевлоковим истраживањима, Солон је своје опште ставове о природи правде превасходно исказивао у поезији. Једна група Солонових песама је дидактична, приказана у садашњем времену и садржи општа ауторова размишљања која се односе на стање у Атини и грчки животни стил тога доба. У другој групи песама Солон говори у прошлом времену специфичним тоном и с политичком сврхом. Симболи правде коришћени у песмама подсећају на тумачења из Хомерове „Илијаде”. У једној од песама Солон истиче да је продаја Атињана у иностранству акт који може бити квалификован као праведан или неправедан, али пошто се продаја сама по себи сматра радњом која је у складу са законом, питање праведности односи се искључиво на форму. Солон разматра силу као (легитимно) процесно средство које се може применити у појединим случајевима, па се тако његова концепција у знатној мери разликује од Хесиодовог принципа према којем законита радња не може бити она која укључује силу. Солон одбацује Хесиодову утопијску идеју неприхватљивости примене силе, иако је не истиче као неопходну. Концепт

59 Плутарх, Славни ликови анӣике I (превео Милош Ђурић), Матица српска, Нови Сад 1990, 78-94.

60 M. Maciejewski, 9. 
Солонове правде се, притом, заснива на правичности која лежи у флексибилности закона (дике у сваком конкретном случају), а не на једнакости. Солон, као и Хесиод пре њега, усваја постојање различитог друштвено-политичког статуса међу људима као природну и непроменљиву чињеницу, премда наглашава да правда може користити и једнима и другима. Препознајући да се у Атини становништво може поделити на две основне класе (богате и сиромашне), Солон закључује да је између тих супротних категорија неопходно успоставити одређено праведно прилагођавање које не треба само славити у песмама већ и регулисати законима. ${ }^{61}$

Солонова дике подразумева напредак и благостање друштва путем економских реформи, због чега се (не)постојање дике не односи на правду и неправду у ширем смислу, већ на законито и незаконито стицање богатства и његов ефекат на заједницу. Тако он прави разлику између стања добро уређеног града (еunoтia) и постизања таквог уређења законима (дике). Иако се противи неправедном и незаконитом стицању имовине, Солон не одређује врсту и природу одговарајуће санкције за неодговарајуће понашање, али прихвата дике као одмазду. Дике је, дакле, узвишена моћ права, и, ако је нема, читава заједница биће кажњена, а не само они који су је повредили. ${ }^{62}$

\section{5. ПРАВДА У ХЕЛЕНСКИМ ТРАГЕДИЈАМА}

У каснијој историји хеленске духовности настају драме о трагичном херојству прожете митским идејама. Трагедије су засноване на митско-религијском, етичком или социјално-политичком гледишту на живот и човека. ${ }^{63}$ Међу многим драмама из тог периода за идеје о правди и правичности најзначајнија су дела Есхила и Софокла, као оне драме које су своје радње темељиле на поимању и тумачењу исправног и праведног по божанским мерилима.

Есхилова „Орестија” из V века п.н.е. садржи елементе хеленских митова из херојског доба, али се принцип праведности заснива на обичајном талиону према којем је казна морала да буде истоветна с почињеним злочином. У трагедији је представљен шири систем правне хијерархије - божји закони стоје изнад људских закона и приватног права а интерес полиса долази испред обичајног права (темис).

61 Eric A. Havelock, The Greek Concept of Justice from Its Shadow in Homer to Its Substance in Plato, Harvard University Press, Cambridge - London 1978, 252-255.

62 M. Gagarin, 190-192.

63 M. Đurić, Istorija helenske etike, 76-87. 
Основна идеја која прожима ово дело заснована је на виђењу и тумачењу људске и божанске правде. По Есхилу, правда је божанска сила, оличена у Зевсу, која успоставља моралну равнотежу космоса. Зевс влада космосом и управља људима одређујући им смисао и сврху. Он је судија у свету живих и мртвих који се стара да кривце увек стигне казна. Есхилова правда је заснована на уравнотеженом божанском поретку космоса, који се одржава одређивањем казне ономе ко моралну равнотежу наруши. Идеја равнотеже почива на принципу праве мере: разборит човек мора да зна да ће му уз прекомерну срећу припасти и део несреће, а ако је несрећан може се надати да ће му судбина донети део среће. Овакав морални поредак космоса исто је што и правда. ${ }^{64} \mathrm{C}$ обзиром на то да сврха казне није првенствено да се казни кривац, већ да се успостави нарушена морална равнотежа, казна не мора одмах и директно да погоди кривца, него може да се одложи и пренесе на његове потомке. Највећи греси за богове јесу обест, осионост, насиље и жеља да се има више него што човеку припада. Овако схваћена, Есхилова правда је апсолутна правда, божанска правда заснована на истини, непогрешивости и неопозивости. Међутим, пошто божанска правда није институционализована него се спроводи људским деловањем, спровођење правде може да изазове још веће неправде и грехе, јер се услед људских несавршености и слабости могу погодити и они који нису кривци. На тај се начин очитава супротност између божанске правде и добра за људску заједницу, које мора да се успостави ублаженом правдом. ${ }^{65}$

У „Орестији” је опеван повратак краља Агамемнона у Микену након пада Троје. Агамемнон је пре Тројанског рата жртвовао своју ћерку Ифигенију да би му богови помогли у Тројанском рату, због чега га је након рата убила жена Клитемнестра, која је потом страдала заједно са својим љубавником од руке сина Ореста. ${ }^{66}$ Проклетство је пратило Агамемнонову породицу још од греха његових предака. Тантал и његови потомци борили су се против бога и једни против других, а Агамемнонов отац је убио децу свога брата и послужио их на својој гозби. Агамемнонов грех је био убиство ћерке Ифигеније, Клитемнестрин грех је било убиство мужа, док је Орестов грех био убиство мајке и мајчиног љубавника заслужног за убиство Агамемноновог оца. У трагедију су се умешали богови. Ериније, богиње освете и персонификације гриже савести, прогањале су Ореста све док

64 Mirjana Stefanovski, Kosta Čavoški, Apsolutna i ublažena pravda u Eshilovoj Orestiji, Naš dom, Beograd 2001, 81-100.

65 Ibid.

66 А-М. Битен, 141-142. 
није, после годину дана лутања, отишао у Атину како би му Ареопаг судио. На суђењу, Орестов бранилац био је бог Аполон, а јавни тужилац је била најстарија Еринија. Гласање у Ареопагу је било нерешено те је богиња Атина дала глас у корист Ореста, након чега је он био ослобођен. ${ }^{67}$

Агамемнонова кривица је у епу приказана двојако - као последица кривице и греха његових предака и као последица личног греха због политичких амбиција. Клитемнестра убија Агамемнона из освете, у духу старог обичајног права према којем се крв мора платити смрћу. Међутим, Клитемнестра такође има амбицију да влада полисом, па убиство није могло да буде оправдано. Лик Агамемнона руши унутрашњу равнотежу породице, а Клитемнестра уз повреду домаћинства и полиса пркоси природном складу и природним законима. ${ }^{68}$ Орестова дилема и грех произилазе из прошлости и наслеђа, истовремено из благослова и клетве. ${ }^{69}$ Иако је Орестов злочин био освета за убиство оца, он је био изведен пред суд. Круг греха и казни морао је да буде затворен одлуком највишег органа у полису, у овом случају гласовима богова. Атина је испитала Ериније и Ореста како би чула мишљења обе стране, а затим оставила пороти да да̂ суд по којем ће она одлучити. ${ }^{70}$ Тако је успостављен концепт законске правде (дике) којим је завршен циклус греха и освете. „Пошто им је обећано светиште које до тада нигде нису имале, Ериније се покоравају пресуди народног суда, држави, као носиоцу и извршиоцу правде и своју осветничку службу предају Ареопагу, као органу Дике, тј. Правде, ћерке Дивове. Богиња Атена чуваће државу споља, а оне као Еумениде, тј. Милостиве стараће се за државу изнутра."71 Према овом принципу, институција суда (која је у трагедији поистовећена с божјом власти), има примат у односу на обичајно право и праведност схваћену према неписаним правилима. Неки аутори сматрају да је са̂ма ослобађајућа одлука за Ореста донета на Ареопагу заправо компромис између прехеленског концепта матријархалног друштва у коме је убиство мајке апсолутно неопростив злочин, и успостављања патријархата у којем је очинска фигура супериорна. ${ }^{72}$

67 V. Djurant, 411-416.

68 J. Peter Euben, "Justice and the Oresteia”, The American Political Science Review 76(1)/1982, 25-26.

69 Ibid., 27.

70 V. Djurant, 411-416.

71 M. N. Đurić, Istorija helenske književnosti, 279.

72 R. Grevs, 425-426. 
Пресуда Ареопага представља ублажавање круте и немилосрдне правде божанским и људским милосрђем. ${ }^{73}$ До ублажавања правде дошло је, такође, у интересу полиса, пре свега ради одржавања унутрашњег реда и мира и избегавања грађанског рата. Ублажена правда није неумитна, она не одговара увек извршеном злочину, али је она институционализована и прилагођена полису јер се заснива на преовлађујућем мишљењу судија које је народ изабрао. Коначно, апсолутна правда је изнад свих вредности, али се ублажава њеним усаглашавањем са другим вредностима у полису. ${ }^{74}$

Ова драма приказује патње људи у сукобу личне природе и датог света. „Орестија” илуструје опасности поноса, непредвидивост политике, крхкост правде и последице радњи које доводе до бола али и до спознаје мудрости. ${ }^{75}$

Један од највећих старогрчких драматурга-трагичара, Софокле, своју драму „Антигона”, такође је засновао на сукобу између два схватања законитости и правде. С једне стране правноетичког сукоба стајале су одлуке моћног Креонта, краља Тебе, а с друге је била борба усамљене Антигоне, фаталистички опредељене за божанске законе. Ове супротстављене личности имају правно упориште за своје понашање, с тим што се захтев и одлука краља Креонта односе на примену закона полиса, а Антигона се бори ослањајући се на религиозно обичајно право које носи моралну обавезу породице. Драма почиње сахраном Антигониног брата Полиника који је изгубио живот борећи се за власт са својим братом близанцем Етеоклом после одласка њиховог оца, краља Едипа, из Тебе.$^{76}$ Браћа су истовремено погинула у двобоју а њихов ујак Креонт је преузео власт и донео одлуку да они који су напали Тебу не смеју бити сахрањени. Креонтова одлука била је заснована на закону Тебе по коме је забрањено сахрањивати непријатеље државе. Међутим, Антигона није могла да прихвати тај закон и краљеву одлуку, сматрајући да је изнад људских закона божји закон, по коме је дужност породице да часно сахрани умрлог. ${ }^{77}$ Антигона је симболично сахранила брата Полиника посувши га земљом, због чега јој је гневни краљ Креонт изрекао смртну казну и наредио да је живу сахране. У низу трагичних догађаја, Антигона извршава самоубиство, након чега Креонтов син, заљубљен у Антигону, такође

73 M. Stefanovski, K. Čavoški, 121-136.

74 Ibid.

75 J. P. Euben, 32-33.

76 Софокле, Анйиі̄она (превео Милош Н. Ђурић), Завод за уџбенике, Београд 2019, 21-25.

77 Ibid., предговор М. Ђурића 15-16. 
себи одузима живот. Његова мајка, Креонтова супруга се убија и несрећни Креонт прижељкује да и њега стигне иста судбина. ${ }^{78}$

Песник указује на побуде понашања појединаца у овој трагедији. Креонт је имао превасходно политички циљ - покушавао да учврсти краљевску власт строгим одлукама и заповестима. ${ }^{79}$ За разлику од њега, Антигонин интерес није почивао на користољубљу, већ искључиво на моралном ставу о обавези спровођења природних закона по којима је породица дужна да прописно сахрани преминуле како би њихова душа могла да оде у Хад. ${ }^{80}$ Драма се завршава хорским певањем „За ковање среће најпрви је маљ да разуман будеш; никада ред не ремети божји." ${ }^{\prime 1}$ Како су захтеви обе стране (упркос обостраном претеривању) „правно основани” са аспекта државе или са аспекта породице, песник завршава драму без победе иједне стране, разрешењем од стране више и божанске правде. ${ }^{82}$

Јединствено тумачење радње у „Антигони” дао је Хегел у својој „Феноменологији духа”. Према Хегелу, сукоб Антигоне и Креонта у драми представља уједно сукоб људског и божанског права, сукоб дужности мушкарца и жене, и сукоб ликова у својим изабраним или датим улогама. Конфликт је био неминован јер су се оба актера стриктно придржавала својих уверења о исправном ауторитету (праву човека или праву богова). Пошто се људска и божанска правда налазе у заокруженој етичкој хармонији, ликови само наизглед доносе одлуке на основу онога чему дају приоритет. Подређеност једном ауторитету (друштвеном или божанском) долази из предодређености појединца. Зато је Антигона као жена била у служби свог оикоса дужног да поштује само вишу правду, док је пуноправни грађанин Креонт морао да буде у служби заједнице и њених усвојених етичких норми. Хегелово виђење Антигоне блиско је његовом коначном закључку о хеленским друштвеним нормама које су истовремено божанске и људске. Сви закони су људски јер су од људи створени и сви закони су божански јер су део врховног ауторитета названог апсолутни дух. ${ }^{83}$ У завршном стиху трагедије препознаје се етички заснована поука, према којем људским законима не треба реметити божји ред

78 Ibid., 21-94.

79 Ibid., поговор М. Ђурића 96.

80 V. Djurant, 421.

81 Софокле, 94.

82 Ibid., поговор М. Ђурића 99.

83 Molly Farneth, „Gender and the Ethical Given: Human and Divine Law in Hegel's Reading of the Antigone", The Journal of Religious Ethics 41(4)/2013, 643-645, 647-649, 663. 
оличен у природним законима, обичајима и религиозним правилима. Уколико се то ипак чини, онда то мора бити у разумној мери и без политичких и личних острашћености у примени несавршених људских закона подложних корекцијама. Истовремено, закључак песника може се тумачити као порука да, не треба ни бескомпромисно примењивати старе религијске обичаје, које ново време неминовно ублажава или превазилази. Описани сукоб између супротстављених интереса државе и породице не може се завршити кажњавањем само једне или победом само друге стране, јер највиша, вечита правда захтева природну равнотежу и помирење оба интереса.

\section{6. ХЕРОДОТ И ПРАВДА}

Поред епских и драматуршких дела античких песника у којима је кроз приказивање радњи богова и људи изношено виђење основних религијских, обичајних и моралних принципа, овим питањима посвећени су и прозни историјски текстови, а пре свега Херодотова „Историја”. У Херодотовом делу се схватање правде може посматрати кроз анализу термина dikaiosyne и употребу речи дике, али и кроз начин на који су приказани догађаји, радње владара или сукоб између полиса. ${ }^{84}$ Херодотова дике појављује се у значењу исправне процедуре, док dikaiosyne има нешто другачији смисао. Неки правни идиоми који укључују реч дике су се први пут појавили у Херодотовим текстовима, у контексту казне за нешто учињено. Реч дике код Херодота означава идентификовање казне која је изречена као резултат процеса. У „Историји” постоји осам појава речи дике распоређених у пет широко расутих контекста, који сви носе један морализујући призвук. ${ }^{85}$

Херодот у свом делу описује догађаје на основу предања свештеника и других људи које је сретао на својим путовањима, али се у његовим приповеткама такође појављују старе народне приче и митолошки прикази. Значај божанског пророчишта опстаје и у причама превасходно историјске садржине. Према Херодоту, деловање богова и њихове награде и казне управљају људским судбинама и историјским догађајима. Херодотово схватање није у потпуности уобличило хеленску идеју правде, ${ }^{86}$ али је, у виду модификације Хомеровог хуманистичког концепта, остварена замисао о устаљеној правди

84 Željko Kaluđerović, „Antički koreni savremenih shvatanja pravde”, Glasnik Advokatske komore Vojvodine: časopis za pravnu teoriju i praksu 3/2019, 353-354.

85 E. A. Havelock, 296-297.

86 Ibid., 306-307. 
којој се појединци морају повиновати да би чинили исправно. Херодот у свом делу нуди религиозно објашњење исхода персијских инвазија, изричито истичући да су богови и јунаци Грцима донели победу над Персијанцима. Божански свет, представљен у целини или делимично, стајао је на страни Грка, помажући им пророчанствима и привиђењима. Међутим, Херодот не истражује божанску мотивацију нити даје експлицитне одговоре, већ представља богове као заштитнике религије и светилишта, који нису штитили само одане поклонике или просто фаворизовали Грке. Приказивањем непосредне, објективне улоге богова у људским биткама и ратовима, Херодот је истакао неопходност поштене борбе и фер поступања, постојања равномерности и једнакости, а уплив божанске правде је служио одржавању природне равнотеже. ${ }^{87}$

Херодот у „Историји” износи и своје виђење правде, било да је она божанска, законска или индивидуална. У Првој књизи, у причи под називом „Међански тиранин Дејок и други владари”, Херодот приповеда о томе како је један мудар човек желео да постане апсолутни владар, а тај циљ је остварио тако што је углед стекао својом праведношћу. Тог човека, који је стремио ка власти, Херодот је окарактерисао као вечито поштеног и правичног. Као правичан судија, он је „знао да је безакоње непријатељ правди”, разумео је да у друштву постоји дубоки антагонизам између „праведног” и „неправедног” те је настојао да своје амбиције оствари концентришући се на праксу спровођења судског поступка. Када су га у Медији поставили за краља био је строги чувар правде, а Херодот наводи да су му тужбе писмено достављали у двор да би на основу њих доносио пресуде које је слао назад из двора. Дејокова „правда” је на овај начин увела писмене акте у судски поступак. ${ }^{8}$ Овим предањем Херодот указује на значај и вредност етичких принципа као што су поштење и правичност, који на индивидуалном плану доносе највише поштовање људима који их примењују. Судије и вршиоци власти имају обавезу примене тих принципа и правила као услова спровођења и примене правде. Симболи праведности у овој причи односе се на политичку борбу против безакоња, а улога правде јесте успостављање реда и одржавање таквог стања. ${ }^{89}$ Прича о постепеном успону Дејока од скромног судије до ауторитарног владара може се сматрати основом

87 Jon D. Mikalson, „Religion in Herodotus”, Egbert J. Bakker, Irene J. F. de Jong, Hans van Wees (eds.), Brill's Companion to Herodotus, Leiden - Boston - Köln 2002, 187-192.

88 Hdt. I 96-100. (коришћено издање: Хероgот̄ова истиорија (превео Милан Арсенић), Дерета, Београд 2018), Е. A. Havelock, 298.

89 E. A. Havelock, 298. 
Херодотовог правног и филозофског мишљења о субјективној улози особе која правилно суди ради постизања оправдане одлуке. У овој причи препознаје се идеја о правди и улози суда, као и приказ прототипова импресивних персонификација правде. ${ }^{90}$

Питање индивидуалног праведног поступања Херодот разматра и у причи о Спартанцу Глауку и Милећанину. Један Милећанин оставио је код Глаука новац на чување пошто је Глаук био надалеко познат као најправеднији човек у Спарти. Глаук му је дао признаницу и заклео се да ће новац предати ономе ко новац затражи са њоме. После извесног времена, синови Милећанина су дошли с признаницом, али их је Глаук одбио рекавши им да се не сећа да је новац примио. Глаук, међутим, није био сигуран у своју одлуку, па је отишао у Делфе по савет како да поступи. Питија је жестоко прекорела Глаука што од богова тражи подршку за грех и неправедан чин. ${ }^{91} \mathrm{У}$ причи о Глауку се примећује како расте значај етике у пословним односима, а правда је представљена као правило којим се ти односи уређују. Пошто су финансијске трансакције још увек биле гарантоване усменим заклетвама и обећањима, Глаук својим непоштеним понашањем не пркоси само дике, већ повређује dikaiosyne као лични интегритет који појединца усмерава ка исправном или неисправном..$^{92}$ Истовремено, у наведеној причи се појављује традиционални концепт правде која је потврђена заклетвом и индивидуално поимање правде у складу са божјим и људским законима.

Прича под именом „Краљ Протеј и прича о Хелени”, 93 говори о отмици Хелене Тројанске, али се не поклапа са приказивањем истих догађаја у Хомеровој „Илијади”. Ипак, с обзиром на Херодотов начин прикупљања грађе (првенствено сакупљање прича од египатских свештеника), његов приказ доприноси мишљењу да су отмица и Тројански рат историјске чињенице. Поред описа догађаја, Херодот је изнео став у односу на питање праведности, узрока и последица тог рата као и у односу на деловање божјих закона на људске радње. Када људи учине велике неправде и злочине, богови одређују казне.

90 Dimka Gicheva-Gocheva, „The Influence of Herodotus on the Practical Philosophy of Aristotle", Labyrinth 18(2)/2016, 108.

91 Hdt. VI 86: „Епикидејевићу Глауче, корисно за тебе сад је / Заклетвом да отмеш новац и да га добијеш сада; / Закуни ти се, јер смрт и на поштена човека чека! / Ал' син заклетве безимен он је, нит руку има / Нит ногу; ал' ипак пребрзо стиже немилосрдно грабећ. / Док целу кућу не сатре и потомство уништи цело, / А часна човека потомство касније пролази боље." Прихвативши Питијин прекор, Глаук је новац вратио.

92 E. A. Havelock, 302.

93 Hdt. II 112-120. 
„Изнећу своје мишљење о томе: све је то бог тако удесио да потпуним уништењем покаже људима да су за велике злочине и неправде богови одредили велике казне. То је заправо моје мишљење." 94

Херодотова „Историја” обилује различитим врстама кажњавања, а институт казне, заједно са сродним темама о злочину и правди, има књижевну, политичку, историјску и филозофску функцију. Херодот приказује текућу интеракцију између Грчке и Азије, амбивалентност људских достигнућа, неправду, симултано постојање људског зла и божанске правде, а догађаје у светској историји повезује у један зачарани круг злочина и казни. ${ }^{95}$ У литератури се проналази тумачење да су казна, освета, узајамност, правда и неправда у Херодотовом делу приказане као силе које покрећу историјске промене и служе у сврху објашњавања односа између догађаја. Учињена неправда подстиче освету, односно успостављање правде, која може бити и несразмерна извршеном злочину. Међутим, Херодот инсистира на улози божанског у људским пословима те су казне средство којим он преноси своју религиозну визију. Казне, осим што пружају везу између историјских догађаја, откривају и Херодотову стварност божанске правде, па је „Историја” прожета његовим религијским уверењем у божанску интервенцију. ${ }^{96}$ Херодот подвлачи да је претерани несклад између учињеног злодела и освете презрен од стране богова, који прекомерну казну сматрају неправдом. Божанска правда, стога, имплицитно надокнађује људски несавршени механизам за кажњавање одговорних. ${ }^{97}$ Херодот, дакле, казну односно освету приказује двојако, као радњу неопходну ради успостављања правде и као недопуштено прекорачење противмере учињеном злу.

Поред уобичајених међуљудских обавеза, емоција и сукоба својствених породичним односима, Херодот чврсто уграђује у структуру свог приповедања и реципрочне обавезе пријатеља уз кажњавање непријатеља. Пријатељство и непријатељство су снажне вредности друштва, а мерило правде се огледа у поступању према једнима или другима. Израз пријатељи (philoi) је обухватао родбину, блиске личне пријатеље и колеге из друштвених и политичких група с којима се дели заједнички идентитет или интереси. Унутар такве заједнице, пријатељи би требало да помажу једни друге, а тамо где

94 Ibid., 120.

95 William Desmond, „Punishments and the Conclusion of Herodotus' Histories”, Greek, Roman, and Byzantine Studies 44/2004, 21.

96 Ibid., 26-29.

97 Emily Baragwanath, „History, Ethnography, and Aetiology in Herodotus' Lybian Logos”, Histos Supplement 11/2020, 175. 
непријатељство замењује пријатељство примењују се правила „негативног реципроцитета", односно освете. Многа Херодотова приповедања указују на проблеме које такви односи могу изазвати, посебно тамо где се уплиће политика било између појединаца или држава. Оно што нарочито интересује Херодота јесте нестабилна граница између легитимних и прекомерних облика великодушности или освета, нарочито у ситуацијама када постоје одређени културолошки сукоби или изражени интензитет емоција. Грчки тирани су редовно формирали читаве мреже савеза пријатеља и такви односи су већински приказани као узајамно подржавајући, али често са деструктивним последицама по њихова друштва. ${ }^{98}$

Питање прекомерне освете и казне Херодот је разматрао у причи о Аркесилају из Кирене, који није прихватио реформе о подели становништва у три филе и подели земље, по којој је две трећине земље било проглашено за заједничку државну својину. Аркесилај је у тим сукобима био побеђен због чега су и он и његова мајка Феретима побегли. Аркесилај и Феретима су покушали да прикупе војску и врате се у Кирену, а када су то успели Аркесилај је послао изасланике у Делфе по пророчанство. Питија му је дала следећи одговор: „Локсије дозвољава да вас четири Аркесилаја и четири Бата владате у Кирени за време осам поколења. Он вам саветује да ни не покушате дуже да владате. Ти буди миран кад се вратиш у своју земљу. Ако тамо нађеш пећ пуну лонаца немој да их испечеш него их изнеси на ветар, а ако запалиш пећ и изнесеш лонце, не иди у земљу око које тече вода, јер ћеш умрети и ти и твој најбољи бик”. Аркесилај је повео Самљане и вратио се у Кирену коју је поново освојио, а своје противнике је извео пред суд док је неколицина побегла у велику кулу. Видевши то, Арексилај је око куле накупио дрва и запалио их, прекасно се сетивши пророчанства да не запали пећ. Мислећи да је по пророчанству Кирена земља опкољена водом, отишао је у Барку. Међутим, тамо су га становници Барке и неки бегунци из Кирене препознали и убили. Тако је Аркесилај умро заправо својом кривицом, јер није послушао пророчанство. Када је његова мајка Феретима чула да јој је син погинуо, побегла је у Египат код намесника Аријанда како би затражила војску за освајање Барке. Феретимини савезници Персијанци, које је упутио Аријандо, опколили су Барку и држали је месецима у опсади, све док је нису на превару освојили. После пада Барке, Персијанци су предали Феретими окривљене грађане Барке, које је она набила на колац, њиховим женама је одсекла дојке и обесила их око градских

98 Nick Fisher, „Popular Morality in Herodotus”, Egbert J. Bakker, Irene J. F. de Jong, Hans van Wees (eds.), Brill's Companion to Herodotus, Leiden - Boston - Köln 2002, 209-210. 
зидина, а остале заробљенике је предала Персијанцима. Међутим, Феретима је и сама умрла мучном смрћу, поједена жива од стране црва и Херодот је закључио да „претерано моћне освете људи могу изазвати завист богова." 99

У причи о заузећу Сеста, Херодот истиче освету као морални чин. Када су Хелени пошли на Хелеспонт, у Сесту је владао обесни и разуздани Персијанац Артаикто, који је преварио краља Ксеркса да му дозволи да преузме кућу и земљу једног човека. Ту се налазила Протезилејева гробница у којој су биле бројне драгоцености, које је Артаикто опљачкао и пренео у Сест. Опсада Сеста од стране Грка је дуго трајала а Артаикто и његов син су напослетку били заробљени. Чувар заробљеника сведочио је о чуду које се тада десило, а огледало се у томе да је усољена риба почела да се праћака као да је жива. Када је то видео, Артаикто је одмах рекао да се то чудо односи на њега и да је то његова казна. Протезилеј, чије је благо опљачкао, иако је давно мртав и балсамован „још увек има божанску снагу да казни оног који га вређа". Стога је Артаикто понудио новац Атињанима и одштету Протезилејевом храму у замену за свој живот и живот свог сина. Међутим, Атињани су тај предлог одбили и пред његовим очима су каменовали сина док су самог Артаикта одвели на обалу и тамо га разапели на крст. ${ }^{100}$ Артаикто је жртвован да би се, због непоштења и скрнављења светилишта (гробнице), задовољио захтев за одговарајућом осветом. Његово распеће може указивати на претерану одмазду од стране Грка, међутим Херодот у својој нарацији користи традиционална морална оправдања за проблематику конкретне освете како би истакао персијске и друге варварске суровости. ${ }^{101}$

\section{7. ЗАКЉУЧАК}

Проучавањем карактера митолошких јунака и њихових поступака, Хелени су отворили вечита питања о правди и односу променљивих закона људи спрам универзалних закона природе. Пратећи трансформацију идеје правде код старих Грка, може се приметити да је тежња ка природној равнотежи била непроменљиви основ на којем је та идеја почивала.

Сједињење права, религије и морала је полазни хеленски концепт правде првобитно оличене у божјем лику (посматраном у политеистичком смислу) и божјим делима, који концепт се, током

99 Hdt. IV 161-202.

100 Hdt. IX 114-120.

101 N. Fisher, 216. 
друштвеног развоја, преображавао у основ уређења индивидуалног и колективног понашања људи. Тако су богиње Темида и Дике у хеленској митологији и литератури носиоци божанске мудрости, истинитости и правде, а потом, персонификације религиозног, филозофског и политичког виђења правде, правичности и закона. Као термини, темис и дике су вишезначне речи, па су њихова значења филозофска, религиозна и обичајна те означавају божје, законодавно и људско уређење.

У старогрчким књижевним делима, људска судбина је условљена одлукама и деловањем богова који награђују или кажњавају понашање људи у складу са божанским правилима правде, правичности и моралности. У Херојском добу, опеваном у Хомеровој „Илијади”, по моралном кодексу је част војничке аристократије била изнад самог живота, а антички јунак је морао да добије праведно задовољење због повреде те части. Почевши од Хомерове „Одисеје”, природна равнотежа правде захтевала је да дође до помирења индивидуалних и колективних интереса. У Есхиловим и Софоклеовим трагедијама још је изразитија трансформација идеје правде заснована на друштвено-политичким променама и хуманизацији целог концепта. Трагичне судбине јунака, оптерећених грешкама предака, који и сами чине страшне грехове применом обичајног талиона, уз божју помоћ и промисао окончавају се у духу новог времена. Наступајуће доба патријархата омогућило је да на скупштини агоре, уз подршку богиње Атине, кривац добије опрост за убиство мајке, које је било неопростиво по дотадашњим религијским и обичајним правилима. Богови успостављају праведну равнотежу у корист јунака погођених тешком судбином, који су се супротставили божјим и људским законима. У митовима и нарацији Херодота свеприсутан је концепт божанског утицаја на људске животе, не само на индивидуалном плану него и у светлу историјских догађаја.

Иако су у античкој Грчкој схватања демократије и слобода свакако била другачија него у модерном друштву, хеленска правда је ипак укључивала све облике праведности и правичности персонификоване у комплексним појмовима темис и дике. Такав вишедимензионални приказ правде указује на постојање свести старих Хелена о нужности очувања моралних вредности у приватном и јавном животу и о евентуалној колизији између права појединаца и права заједнице.

Са античким митовима о Темис и Дике, еповима, трагедијама и прозним делима, започета су разматрања идеје правде, праведности и правичности, као и божјих и људских закона и судских одлука. 


\section{БИБЛИОГРАФИЈА}

\section{ИЗВОРИ:}

Heraklit, Fragmenti (priredio Miloš Đurić), Grafos, Beograd 1979.

Хероgотиова истиорија (превео Милан Арсенић), Дерета, Београд 2018.

Hesiod, Poslovi i dani, Postanak bogova, Homerove himne (preveo Branimir Glavičić), Demetra - Filološka biblioteka Dimitrija Savića, Zagreb 2005.

Hesiod, Theogony, Works and Days, Testimonia (edited and translated by Glenn W. Most), Harvard University Press, Cambridge - London 2006.

Homer, Odiseja (preveo Panajot Papakosopulos), Karpos, Loznica 2013.

Homer, Ilijada (preveo Miloš N. Đurić), Dereta, Beograd 2015.

Publije Ovidije Nason, Metamorfoze (preveo Tomo Maretić), Matica Hrvatska, Zagreb 1907.

Плутарх, Славни ликови анӣике I (превео Милош Ђурић), Матица српска, Нови Сад 1990.

Софокле, Анйиі̄она (превео Милош Н. Ђурић), Завод за уџбенике, Београд 2019.

\section{ЛИТЕРАТУРА:}

Sima Avramović, „Gnome dikaiotate - pravo, pravda i pravičnost u atinskoj sudnici”, Jasminka Hasanbegović (ur.), Pravo i pravda 2013, Univerzitet u Beogradu - Pravni fakultet, Beograd 2019, 19-39.

Emily Baragwanath, „History, Ethnography, and Aetiology in Herodotus' Lybian Logos", Histos Supplement 11/2020, 155-188.

John Bertrand Lott, „An Augustan Sculpture of August Justice”, Zeitschrift für Papyrologie und Epigraphik 113(1996), 263-270.

Ан-Мари Битен, Сйара Грчка, Clio, Београд 2010.

Коста Чавошки, О йравgи и йравичносӣu, САНУ, Београд 2017.

William Desmond, „Punishments and the Conclusion of Herodotus' Histories”, Greek, Roman, and Byzantine Studies 44/2004, 19-40.

Matthew W. Dichie, „Dike as a Moral Term in Homer and Hesiod”, Classical Philology 73(2)/1979, 91-101.

Vil Djurant, Istorija civilizacije: Život Grčke, Narodna knjiga, Beograd 1996.

Pamela Donleavy, Ann Shearer, From Ancient Myth to Modern Healing (Themis: Goddess of Heart-Soul, Justice and Reconciliation), Routledge, London New York 2008.

Miloš Đurić, Istorija helenske etike, BIGZ, Beograd 1976.

Miloš N. Đurić, Istorija helenske književnosti, Zavod za udžbenike i nastavna sredstva, Beograd 1996. 
J. Peter Euben, „Justice and the Oresteia”, The American Political Science Review $76(1) / 1982,22-33$.

Jane Ellen Harrison, Themis - A Study of the Social Origins of Greek Religion, Cambridge University Press 1912.

Molly Farneth, „Gender and the Ethical Given: Human and Divine Law in Hegel's Reading of the Antigone", The Journal of Religious Ethics 41(4)/2013, 643-667.

Nick Fisher, „Popular Morality in Herodotus”, Egbert J. Bakker, Irene J. F. de Jong, Hans van Wees (eds.), Brill's Companion to Herodotus, Leiden - Boston Köln 2002, 199-224.

Michael Gagarin, „Dike in Archaic Greek Thought”, Classical Philology 69(3)/1974, 186-197.

Robert Grevs, Grčki mitovi, Miba books, Beograd 2017.

Dimka Gicheva-Gocheva, „The Influence of Herodotus on the Practical Philosophy of Aristotle", Labyrinth 18(2)/2016, 104-116.

Eric A. Havelock, The Greek Concept of Justice from Its Shadow in Homer to Its Substance in Plato, Harvard University Press, Cambridge - London 1978.

Jasminka Hasanbegović, „Predgovor”, Jasminka Hasanbegović (ur.), Pravo i pravda 2013, Univerzitet u Beogradu - Pravni fakultet, Beograd 2019, 7-18.

Karl-J. Hölkskamp, „Written Law in Archaic Greece”, Proceedings of the Cambridge Philological Society 38/1992, 87-117.

Željko Kaluđerović, Presokratsko razumevanje pravde, Izdavačka knjižarnica Zorana Stojanovića, Sremski Karlovci - Novi Sad 2013.

Željko Kaluđerović, „Antički koreni savremenih shvatanja pravde”, Glasnik Advokatske komore Vojvodine: časopis za pravnu teoriju i praksu 3/2019, 348-363.

H. D. F. Kito, Grci, Prosveta, Beograd 2008.

P. S. Kohan, Istorija stare grčke književnosti, Izdavačko preduzeće „Veselin Masleša”, Sarajevo 1973.

Marek Maciejewski, „The Relationship between Natural and Statutory Law in Ancient and Medieval Concepts”, Księgarnia Akademicka, Politeja 48/2017, $5-22$.

Miroslav Marković, Studije o religiji antike, Jasen, Nikšić 2001.

Jon D. Mikalson, „Religion in Herodotus”, Egbert J. Bakker, Irene J. F. de Jong, Hans van Wees (eds.), Brill's Companion to Herodotus, Leiden - Boston Köln 2002, 187-198.

Gerasimos Santas, „Plato on Inequalities, Justice and Democracy”, Georgios Anagnostopoulos, Gerasimos Santas (ed.), Democracy, Justice, and Equality in Ancient Greece: Historical and Philosophical Perspectives, Philosophical Studies Series vol. 132, 161-178.

Mirjana Stefanovski, Kosta Čavoški, Apsolutna i ublažena pravda u Eshilovoj Orestiji, Naš dom, Beograd 2001.

Stefan Weinstock, Divus Julius, Oxford University Press, London 1971. 


\title{
Isidora FÜRST ${ }^{*}$
}

\author{
THEMIS AND DIKE - \\ JUSTICE IN GREEK MYTH AND TRADITION
}

\begin{abstract}
Summary
The understanding of law in Ancient Greece was based on the religious interpretations of human nature and natural laws. Two Greek goddesses were representatives of justice and fairness. In the ancient sources Themis is presented as a goddess and prophetess, one of the Titans and the daughter of Gea and Uranus. She is a symbol of divine order, justice, natural law and good customs. Dike, the daughter of Themis, is the goddess of justice and truth, the protector of rights and courts of justice, the arbiter, the symbol of honor, the goddess of revenge and punishment. In early Greek culture and poetry, the terms themis and dike represented justice in the meaning of cosmic order, natural law, and legality. The paper analyses the Hellenic notions of justice, fairness and legality embodied in the phenomena of themis and dike. Nomos (law) is just only if it is in harmony with themis, and law is valid only if it is just. The paper presents the doctrines of Hellenic writers, poets and playwrights on justice and law, with special reference to the influence of mythology on Hellenic law. Publius Ovidius Naso's work „Metamorphosis”, which speaks about Themis' role in the creation of the world and the salvation of the human race is one of the greatest sources about this goddess. In Homer's "Iliad” and „Odyssey”, epics that sing of the heroic spirit, justice is shown in the motives, intentions and behavior of the participants in the event, mostly heroes. The poet Hesiod, famous for the poems „Theogony” and „Works and Days”, moves away from the heroic virtues of people and portrays the gods as bearers of moral power and guardians of justice. In the light of legislative reforms, Solon's dike represents the progress and well-being of society through economic reforms, which is why justice and injustice refer only to legal and illegal acquisition of wealth and its effect on the community. Aeschylus' "Oresteia” shows the principle of justice based on talion, according to which the punishment has to be identical with the committed crime. One of the greatest Ancient Greek playwrights, Sophocles, based his play „Antigone” on the conflict between the laws of men and the laws of gods. According to Herodotus, the greatest Ancient Greek historian, the actions of the gods govern human destinies and historical events. The idea of justice in Ancient Greece was all throughout its transformation based of the universial concept of natural balance.
\end{abstract}

Key words: Greek mythology. - Justice. - Equity. - Themis. - Dike.

Рад приспео / Paper received: 11.4.2021. Прихваћен за објављивање / Accepted for publication: 7.6.2021.

* The author is a second-year graduate student at the University of Belgrade Faculty of Law, isidora.first@gmail.com. This is a revised version of the paper presented on the Second international student conference Iustoria 2021. 